\title{
Methods of estimating liner compression
}

\author{
S. Leonardi, ${ }^{*}$ J. F. Penry, $\dagger^{1}$ F. M. Tangorra, ${ }^{*}$ P. D. Thompson, $\ddagger$ and D. J. Reinemann $\ddagger$ \\ *Department of Health, Animal Science and Food Safety, Università degli Studi di Milano, 20133 Milano, Italy \\ †Department of Dairy Science, and \\ ‡Department of Biological Systems Engineering, University of Wisconsin, Madison 53706
}

\section{ABSTRACT}

The aim of this study was to compare 2 methods of measuring overpressure (OP) using a new test device designed to make OP measurements more quickly and accurately. Overpressure was measured with no pulsation $\left(\mathrm{OP}_{\mathrm{np}}\right)$ and with limited pulsation $\left(\mathrm{OP}_{\mathrm{lp}}\right)$ repeatedly on the same cow during a single milking. Each of the 6 liners ( 3 round liners and 3 triangular liners) used in this study were tested on the same 6 experimental cows. Both $\mathrm{OP}_{\mathrm{np}}$ and $\mathrm{OP}_{\mathrm{lp}}$ were measured on all 4 teats of each experimental cow twice for each liner. The order of $\mathrm{OP}_{\mathrm{np}}$ and $\mathrm{OP}_{\mathrm{lp}}$ alternated sequentially for each cow test. The OP results for the 6 liners were also compared with liner compression estimated on the same liners with a novel artificial teat sensor (ATS). The $\mathrm{OP}_{\mathrm{lp}}$ method showed small but significantly higher values than the $\mathrm{OP}_{n p}$ method (13.9 vs. $\left.13.4 \mathrm{kPa}\right)$. The $\mathrm{OP}_{\mathrm{lp}}$ method is recommended as the preferred method as it more closely approximates normal milking condition. Overpressure values decreased significantly between the first and the following measurements, (from 15.0 to $12.4 \mathrm{kPa}$ ). We recommend performing the OP test at a consistent time, 1 min after attaching the teatcup to a well-stimulated teat, to reduce the variability produced by OP changing during the peak flow period. The new test device had several advantages over previously published methods of measuring OP. A high correlation between OP and liner compression estimated by the ATS was found, but difficulties were noted when using the ATS with triangular liners.

Key words: liner compression, overpressure, artificial teat sensor

\section{INTRODUCTION}

Vacuum applied to the teat during the milk phase, or b-phase, of pulsation unfolds the teat canal and allows milk to be removed from the teat sinus. This vacuum also causes blood and other tissue fluids to accumulate

Received January 25, 2015

Accepted June 11, 2015.

${ }^{1}$ Corresponding author: penry@wisc.edu in teat tissues. The action of liner compression $(\mathbf{L C})$, applied during the rest phase, or d-phase, of pulsation, helps to maintain milk flow by removing accumulated fluids in teat-end tissues. The LC has been estimated in (1) experiments with live teats (Thompson, 1978; Mein and Williams, 1984; Gates and Scott, 1986: Mein et al. 1987), (2) artificial teat-sensor devices (Caruolo, 1983, Gates and Scott, 1986; Reinemann et al., 1994; Davis et al., 2001; van der Tol, 2010), and (3) mathematical models (Butler, 1993).

The force applied to the teat end by the collapsed liner was described as compressive load by Mein et al. (1987). A more recent definition of LC has been proposed by Mein et al. (2003) as the compressive pressure, over and above the pressure of air in the pulsation chamber, which is applied by a liner to the teat apex during the late c-, d-, or early a-phases of a pulsation cycle. The LC reaches its maximum steady value during the d-phase of the pulsation cycle (Mein and Reinemann, 2009; Reinemann, 2012; Mein et al., 2013).

Liner compression has been shown to influence peak milking speed and the occurrence of teat-end hyperkeratosis (Zucali et al., 2008). The link between increasing LC and elevated peak milk flow was also reported by Bade et al. (2009). In a large Dutch study, the association between teat hyperkeratosis and clinical mastitis illustrated that liner design factors that increased the risk of hyperkeratosis developing also increased the risk of new mastitis infection (Neijenhuis et al., 2001). Liner compression is a function of the physical dimensions, material properties, and mounting characteristics (e.g., mounted tension) of the liner, in addition to pressure difference applied across the collapsed liner during the d-phase of pulsation. It can also be influenced by teat dimension and liner teat fit (Reinemann, 2012). The difficulties of measuring $\mathrm{LC}$ have been reported by Mein et al. (2013).

Overpressure (OP) has been proposed as a robust and practical method to estimate the relative value of LC across liners (Mein et al., 1987, 2003). Overpressure is defined as the pressure difference across the liner at which milk flow just starts or stops. Overpressure is not a direct measure of LC, but can provide a biologically 
Table 1. Selected liner characteristics

\begin{tabular}{|c|c|c|c|c|c|c|c|c|}
\hline Liner & Material $^{1}$ & Shape $^{2}$ & $\begin{array}{c}\mathrm{MP}^{3} \\
\text { depth } \\
(\mathrm{mm})\end{array}$ & $\begin{array}{c}\text { MP } \\
\text { diameter } \\
(\mathrm{mm})\end{array}$ & $\begin{array}{c}\text { Mid-barrel } \\
\text { diameter } \\
(\mathrm{mm})\end{array}$ & $\begin{array}{c}\text { Wall } \\
\text { thickness } \\
(\mathrm{mm})\end{array}$ & Venting $^{4}$ & $\begin{array}{c}\mathrm{TPPD}^{5} \\
(\mathrm{kPa})\end{array}$ \\
\hline A & NR & $\mathrm{R}$ & 34 & 22.0 & 21.0 & 2.1 & none & 10.3 \\
\hline B & NR & $\mathrm{R}$ & 31 & 23.5 & 22.5 & 2.6 & none & 18.7 \\
\hline $\mathrm{C}$ & NR & $\mathrm{R}$ & 31 & 23.5 & 22.5 & 2.6 & none & 18.2 \\
\hline D & NR & $\mathrm{T}$ & 29 & 21.0 & 21.0 & 1.8 & none & NA \\
\hline $\mathrm{E}$ & NR & $\mathrm{T}$ & 35 & 21.0 & 21.0 & 2.0 & $\mathrm{MPC}$ & NA \\
\hline $\mathrm{F}$ & $\mathrm{S}$ & $\mathrm{T}$ & 41 & 21.0 & 24.0 & 2.0 & SMT & NA \\
\hline
\end{tabular}

${ }^{1} \mathrm{NR}=$ nitrile rubber; $\mathrm{S}=$ silicon.

${ }^{2} \mathrm{R}=$ round; $\mathrm{T}=$ triangular.

${ }^{3} \mathrm{MP}=$ mouthpiece; MP depth measured with $40 \mathrm{kPa}$ applied to SMT.

${ }^{4} \mathrm{SMT}=$ venting in short milk tube; $\mathrm{MPC}=$ venting in mouthpiece chamber.

${ }^{5} \mathrm{TPPD}=$ touch point pressure difference; only applicable to round liners (NA = not applicable).

relevant indicator of the relative values of $\mathrm{LC}$ because it is a method that uses live teats in near milking conditions (Reinemann, 2012; Mein et al., 2013). The original test methodology for OP (Mein et al., 2003) involved removing the short pulse tube from 1 teat cup (thereby deactivating pulsation) and increasing the vacuum using a hand vacuum pump until milk flow was observed. Gomez (2010) developed a dynamic OP method in which the pulsator remained active, with vacuum in the pulsation chamber increased in steps of $2 \mathrm{kPa}$ until milk flow was observed in all quarters of an individual cow. This test method allowed for more rapid collection of OP observations, thus facilitating a large sample size of OP measurements, but required modification of the milking installation. The dynamic method produced OP values lower than the original OP method (Reinemann, 2012), but these measurements were done on different population of dairy cows.

The aim of our study was to further advance OP test methods by developing a new test device that would allow for OP measurements of 4 quarters of 1 cow simultaneously, and without requiring modification of the milking installation. The primary objective was to compare 2 methods of measuring OP, both with and without active pulsation, and to examine differences in OP measurements during the peak flow period. A secondary objective of our study was to compare OP measurements with LC measurements made with a novel artificial teat sensor.

\section{MATERIALS AND METHODS}

\section{OP Measurements}

Two different methods of measuring $\mathrm{OP}$ were tested: (1) with no pulsation $\left(\mathbf{O P}_{\mathbf{n p}}\right)$ in a way similar to the original OP method (Mein et al., 2003) but with a shorter period of liner collapse; and (2) with limited pulsation $\left(\mathbf{O P}_{\mathrm{lp}}\right)$ in a way similar to the method reported by Gomez (2010) but with finer measurement resolution. Overpressure was measured in increments of $0.1 \mathrm{kPa}$ for each teat on each cow with both methods, which was the precision of the measuring device vacuum gauge. Test were performed at the University of Wisconsin-Madison Dairy Cattle Center in a $6 \times 6$ parallel milking parlor with low-level milk line, with system vacuum level of $42.3 \mathrm{kPa}$. Six commercially available liners were tested: 3 round liners $(\mathrm{A}, \mathrm{B}, \mathrm{C})$, and 3 triangular liners (D, E, F). The main characteristics of each liner are summarized in Table 1. Six dairy cows (Holstein-Friesian) with premilking teat length between 40 and $50 \mathrm{~mm}(46.8 \pm 6.8 \mathrm{~mm})$ were selected from the herd so that the teat end would be positioned in the part of the liner that is able to collapse and provide compression, according to Reinemann and Mein (2011).

The 6 cows were distributed across early, mid-, and late lactation (54-308 DIM) with a parity range of 1-4, and an average milk yield of $36.8 \pm 9.9 \mathrm{~kg} /$ cow per day. Each liner was tested for 1 milking on each of the cows selected on 6 consecutive milkings (4 morning milkings and 2 evening milkings).

The OP measurements were made using a new test device, the OP Bucket (OPB), designed and built by Milkline s.r.l. (Podenzano, Italy) in collaboration with the Università degli Studi di Milano. With this device, the pulsation chamber vacuum (PCV) at which milk flow starts could be measured on each individual teat. The OPB consisted of a 30-L milking bucket equipped with the following automation and pressure regulation components installed on the lid of the bucket (Figure 1):

- a digital vacuum sensor (ZSE30-01-25L, SCM Pneumatics, Japan, Tokyo) to display the vacuum level in the bucket; 


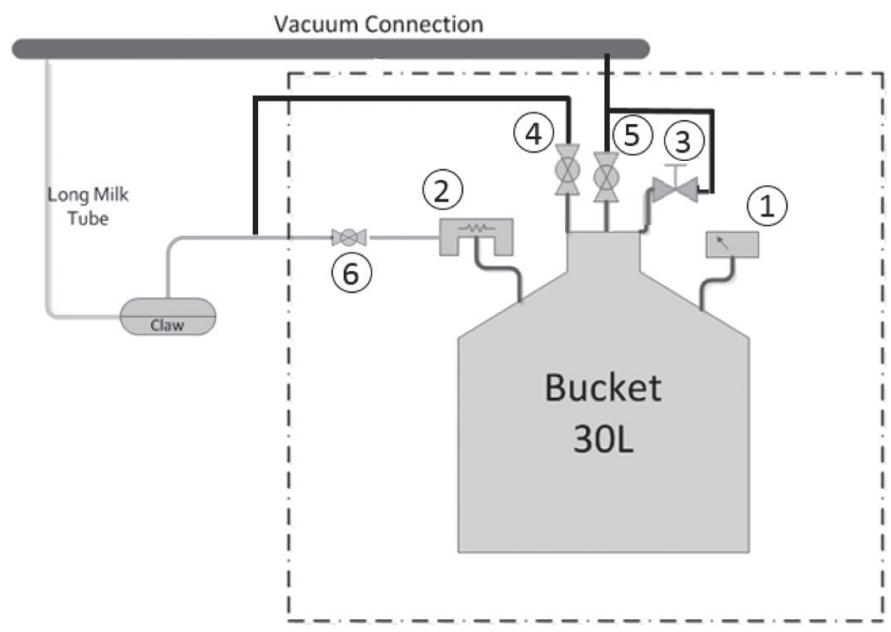

Figure 1. Layout of the overpressure bucket and its connections to the milking machine: (1) digital vacuum sensor; (2) electronic servopulse pulsator; (3) needle valve (4 and 5) open and close valves (V1 and V2); and (6) small open and close valves (v1 and v2) on long pulse tube.

- a battery-powered servo-pulse pulsator (Milkline s.r.l.);

- a needle valve to gradually increase the vacuum level in the bucket; and

- valves to connect the bucket to the vacuum source, atmospheric air, and pulsation tubes.

Cows were prepared for milking by predipping, forestripping, and drying all 4 quarters. The cluster was attached about $90 \mathrm{~s}$ after completion of this preparation procedure. Overpressure measurements were made 1 min after the cluster attachment and at 1-min intervals until 4 OP measurements were completed (test order). The measurement sequence $\left(\mathrm{OP}_{\mathrm{np}}, \mathrm{OP}_{\mathrm{lp}}, \mathrm{OP}_{\mathrm{np}}, \mathrm{OP}_{\mathrm{lp}}\right)$ was reversed $\left(\mathrm{OP}_{\mathrm{lp}}, \mathrm{OP}_{\mathrm{np}}, \mathrm{OP}_{\mathrm{lp}}, \mathrm{OP}_{\mathrm{np}}\right)$ from one cow to the next. Whereas the measurements were conducted up to 5 min after unit attachment, the total elapsed time during which milk is flowing was closer to $2.5 \mathrm{~min}$. Cows with long peak milk flow times were selected for this experiment.

The $\mathrm{OP}_{\mathrm{np}}$ was measured with the pulsator was turned off and applying a gradual increase in PCV, starting from $0 \mathrm{kPa}$. The vacuum level at which milk flow was first observed was recorded for each quarter. It was estimated that test accuracy was within $0.2 \mathrm{kPa}$ for each observation. The $\mathrm{OP}_{l p}$ was measured in the same was as $\mathrm{OP}_{\mathrm{np}}$, but with the pulsator operating.

\section{Artificial Teat Sensor}

An artificial teat sensor (ATS) adapted from Davis et al. (2001) was developed to measure LC directly (Figure 2). A resistive force sensor (FlexiForce B201 Sen- sors, Tekscan Inc., South Boston, MA) was mounted on flat plastic plate $186 \mathrm{~mm}$ long $\times 2 \mathrm{~mm}$ thick $\times 19 \mathrm{~mm}$ wide (with a $9.5-\mathrm{mm}$ radius rounded end). The active area of the resistive force sensor was a $9.5-\mathrm{mm}$ diameter disc that was placed so that the end of the active area of the sensor was at the end of the rounded end of the flat plastic plate. The signal from the sensor was shown to respond to bending and shear as well as forces applied perpendicular to the sensor when demounted from the ATS components. Because of this, the sensor was mounted on the flat rigid plate to eliminate the sensor surface bending. The load cell was calibrated using a 4-point method with dead weights over the known active area of the resistive load sensor. The sensor exhibited excellent linearity based on this calibration test. The end of the sensor was covered with a 30-mm long $\times 19$-mm diameter cylinder with spherical cap end molded of silicone gel with a Shore-A hardness 10 to approximate the biomechanical properties of teat tissue based on assessment of a sample of teats with a durometer. The silicone teat apex was the covered with a close fitting latex glove finger to approximate the physical properties of teat skin. The physical properties of the sensor were designed to approximate those of live teats as LC has been shown to be influenced by the hardness of ATS (Davis et al., 2001).

Liner compression measurements were done using the ATS on the same 6 liners used for OP testing. For round liners, the ATS was inserted so that the flat center plate of the sensor was aligned with the collapse plane of the liner. This plane was determined through repeated observations of the liner collapsing when vacuum was applied to the short milk tube. For triangular liners, LC measurements were done with the sensing surface facing a flat side of the liner and then repeated with the sensing surface facing the corner of the liner (Figure 2). Liner compression was measured with the teat sensor at an insertion depth of $60 \mathrm{~mm}$ in the liner to approximate the position of the teat end for the selected teats, characterized by a premilking teat length of 40 to $50 \mathrm{~mm}$. Measurements were performed at a pressure difference (PD) across the liner (vacuum in the short milk tube) from 30 to $50 \mathrm{kPa}$ in $5-\mathrm{kPa}$ increments.

\section{Statistical Analysis}

Data were analyzed using the SAS version 9.3 system (SAS Institute Inc., Cary, NC). The PROC MIXED procedure was used to test for differences in OP with cow and cow by teat as random effects, cow by teat as repeated effect, and liner, test method, test order, and the interaction of test method by test order, liner by test method, and liner by test order as fixed ef- 


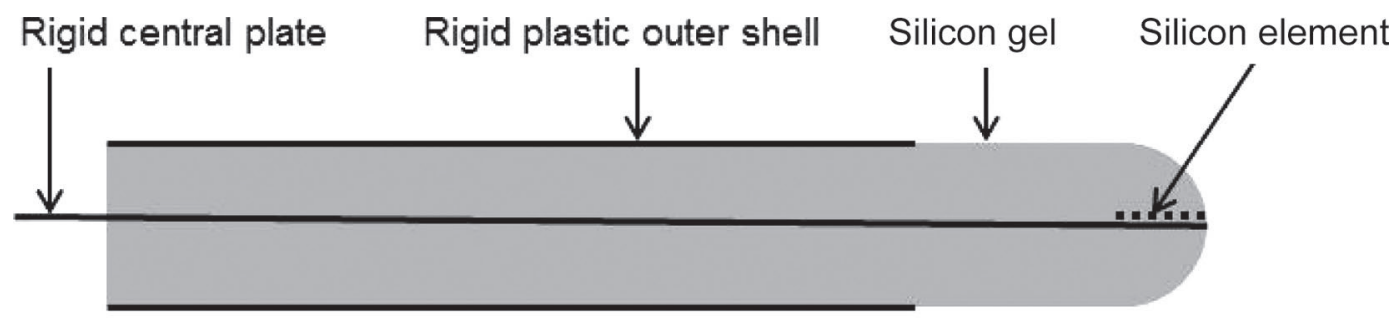

Side view
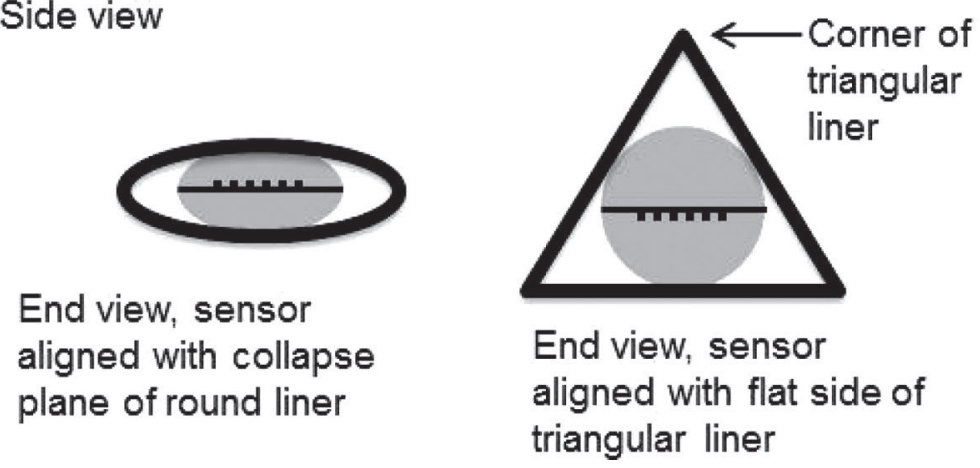

Figure 2. Diagram of the artificial teat sensor (ATS) illustrating placement and orientation of the ATS within collapsing round and triangular liner examples.

fects. Terms that were not significant $(P>0.05)$ were removed from the model. The initial model was:

$$
\begin{gathered}
\mathrm{Y}_{\mathrm{ik}}=\mu+\mathrm{TM}_{\mathrm{i}}+\mathrm{TO}_{\mathrm{j}}+\mathrm{L}_{\mathrm{k}}+\mathrm{TM} \times \mathrm{TO}_{\mathrm{ij}}+\mathrm{TM} \\
\times \mathrm{L}_{\mathrm{ik}}+\mathrm{TO} \times \mathrm{L}_{\mathrm{jk}}+\mathrm{TM} \times \mathrm{TO} \times \mathrm{L}_{\mathrm{ijk}}+e_{\mathrm{ik}},
\end{gathered}
$$

where $\mathrm{Y}_{\mathrm{ik}}=\mathrm{OP} ; \mu=$ overall mean; $\mathrm{TM}_{\mathrm{i}}=$ effect of test method ( $\mathrm{i}=\mathrm{np}, \mathrm{lp}) ; \mathrm{TO}_{\mathrm{j}}=$ effect of test order $(\mathrm{j}=1-4) ; \mathrm{L}_{\mathrm{k}}=$ effect of liners $(\mathrm{k}=1-6) ; \mathrm{TM} \times \mathrm{TO}_{\mathrm{ij}}$ $=$ interaction test method by test order; $\mathrm{TM} \times \mathrm{L}_{\mathrm{ik}}=$ interaction test method by liner; $\mathrm{TO} \times \mathrm{L}_{\mathrm{jk}}=$ test order by liner; $\mathrm{TM} \times \mathrm{TO} \times \mathrm{L}_{\mathrm{ijk}}=$ interaction test method by test order by liner; and $e_{i k}=$ random error with zero mean and variance. Results were reported as least squares means, significance was declared at $P<0.05$. Descriptive statistics of LC data were calculated for each liner and the PROC CORR procedure of SAS 9.3 (SAS Institute Inc.) was used to assess Pearson correlation coefficients between $\mathrm{OP}$ and $\mathrm{LC}$ values measured for each liner.

\section{RESULTS AND DISCUSSION}

\section{OP Measurements}

Overpressure values were recorded as $0.0 \mathrm{kPa}$ for all tests of liner $\mathrm{F}$ as milk flow was present for all quarters for when PCV was $0 \mathrm{kPa}$ (atmospheric pressure) for all tests. As no variability in OP was associated with liner $\mathrm{F}$, it was not included in further statistical analysis. The main effects of liner $(P<0.0001)$, test order $(P<0.0001)$, and test method $(P=0.012)$ were significant. An interactive effect between test order and test method was observed with $\mathrm{OP}_{l p}$ values decreased significantly across time, from the first measurement $(15.7 \mathrm{kPa})$ to the fourth one $(11.8 \mathrm{kPa})$, and a declining trend for $\mathrm{OP}_{n p}$ with a significant difference between first and fourth but no significant differences between the first and second or third and fourth measurements. The $\mathrm{OP}_{\mathrm{np}}$ measurements were thus less affected by test order than were $\mathrm{OP}_{l p}$ measurements. Interactive terms test method $\times$ liner, test order $\times$ liner, and test method $\times$ test order $\times$ liner were not statistically significant and were dropped from the final model.

The $\mathrm{OP}_{l p}$ values were slightly higher than $\mathrm{OP}_{n p}$ values (13.9 vs. $13.4 \mathrm{kPa}$ ), as shown in Table 2. This differs from previous results of Mein et al. (2003) and Gomez (2010), in which the $\mathrm{OP}_{\text {lp }}$ values were about $30 \%$ lower than $\mathrm{OP}_{\mathrm{np}}$ measurements for the same liner type. These studies used different populations of cows and the test methods were also somewhat different than the ones used in our study.

Differences in OP Resolution. Gomez (2010) measured $\mathrm{OP}_{\mathrm{lp}}$ staring with $2 \mathrm{kPa}$ in the pulsation chamber with stepwise increases of $2 \mathrm{kPa}$. Our method started with $0 \mathrm{kPa}$ in the pulsation chamber and allowed for better resolution of OP measurements (0.1 $\mathrm{kPa})$.

Differences Across Cows and Teats. Teat length and shape influenced OP values. Mein et al. (2003) and 
Table 2. Overpressure (OP) measured using the 2 different methods: with no pulsation $\left(\mathrm{OP}_{\mathrm{np}}\right)$ and with limited pulsation $\left(\mathrm{OP}_{\mathrm{lp}}\right)$

\begin{tabular}{lc}
\hline Test method & LSM \pm SEM \\
\hline $\mathrm{OP}_{\mathrm{np}}$ & $13.43 \pm 1.45^{\mathrm{a}}$ \\
$\mathrm{OP}_{\mathrm{lp}}$ & $13.89 \pm 1.45^{\mathrm{b}}$ \\
\hline
\end{tabular}

${ }^{\mathrm{a}, \mathrm{b}}$ Different letters within a column denote significant difference $(P<$ $0.05)$.

Gomez (2010) used different groups of cows with different teat lengths and teat diameters that could partially differences in $\mathrm{OP}$ values. We tested both methods $\left(\mathrm{OP}_{\mathrm{lp}}\right.$ and $\mathrm{OP}_{\mathrm{np}}$ ) on the same group of cow with homogeneous teats, ranging between 40 and $50 \mathrm{~mm}$, during the same field test.

Differences in Liner-Closed Duration. Mein et al. (2003) made $\mathrm{OP}_{\underline{n} \mathbf{p}}$ measurements by removing the short pulse tube from 1 teat cup, and then slowly increasing PCV using a hand pump until milk flow was observed. This method provided a very long liner-closed, or d-phase, of pulsation (up to $30 \mathrm{~s}$ ). Our method allowed for a liner-closed period of less than $3 \mathrm{~s}$.

Differences in Liner-Opening Duration. The pulsation-less method used by Mein et al. (2003) to measure $\mathrm{OP}_{\mathrm{np}}$ may have resulted in teat end congestion occurring during the slow opening of the liner (also up to $30 \mathrm{~s}$ ). Teats have been shown to start to congest about $500 \mathrm{~ms}$ after the liner is opened (Williams et al., 1981). Gomez (2010) found that the limited pulsation applied while measuring $\mathrm{OP}_{l p}$ was less likely to result in teat end congestion than normal milking. This could explain why the $\mathrm{OP}_{1 \mathrm{p}}$ values found by Gomez (2010) were lower than the $\mathrm{OP}_{\mathrm{np}}$ values reported by Mein et al. (2003).

Our system allowed measuring $\mathrm{OP}_{\mathrm{np}}$ about one-third of the time $(10 \mathrm{~s})$ as required by Mein et al. (2003), whereas the time measuring $\mathrm{OP}_{\mathrm{lp}}$ was comparable with Gomez (2010). This could explain why the difference in our $\mathrm{OP}_{n p}$ and $\mathrm{OP}_{\mathrm{lp}}$ measurements was smaller (0.5 $\mathrm{kPa}$ ) than the difference reported previously. With our method, OP measurements were able to be completed in less than $30 \mathrm{~s}$, and could be performed multiple times on the same cow within a single milking. Because milk flow ceases from individual quarters during OP measurement, the normal peak flow period is extended as a result. We were also able to switch between the $\mathrm{OP}_{l p}$ method to the $\mathrm{OP}_{\mathrm{np}}$ methods multiple times during a single cow milking, thus providing a more reliable comparison of the 2 methods by reducing across-milking variability.

Overpressure values decreased steadily from the first $(15.0 \mathrm{kPa})$ to the fourth test $(12.4 \mathrm{kPa})$, as shown in Table 3. Similar OP values decreasing over time were found during an experimental trial performed with the
OPB on 5 round European liners tested in 3 different dairy farms (F. M. Tangorra, unpublished data). In that study, a significantly decrease of about $3 \mathrm{kPa}$ in $\mathrm{OP}$ values were recorded, using the $\mathrm{OP}_{\mathrm{lp}}$, at one and 3 min from the beginning of the milking. Additionally, a positive significant correlation was found between teat lengths and $\mathrm{OP}$ values measured at $1 \mathrm{~min}$ after the milking unit attachment, but not at 3 min of milking. Reasons for this change in observed OP during the progression of a single milking for an individual cow have not been determined but could include factors such as subtle changes in the position of the teat within the liner, small changes in teat sinus pressure, or a slight relaxation of teat end musculature. These results suggest that setting a standard period after the cluster attachment on an individual cow to perform the OP measurements is appropriate to make the future measurement values repeatable and comparable. As a guideline, taking into account that peak milk flow is usually reached after $30 \mathrm{~s}$ when cows are properly prepared, and also avoiding potential effects of the teat penetration into the liner on the $\mathrm{OP}$ values, measurements should be made at a standard time of 1 min after teat cup attachment, as previously suggested by Mein et al. (2003). Measurements taken in this way $\left(\mathrm{OP}_{\mathrm{lp}}\right.$, test order 1) for the 6 assessed liners are reported in Table 4. Based on power calculations for this research $(\alpha=0.05, \beta=0.8)$, if a $1-\mathrm{kPa}$ resolution in $\mathrm{OP}$ is the desired outcome, 20 teats ( 5 cows) should be assessed. The number of teats can be reduced to 12 ( 3 cows) where a $2-\mathrm{kPa}$ OP resolution is sought for test liners. Cows should be carefully selected such that assessed teats are predicted to be in the liner collapse zone during milking.

The OP was significantly higher for round liners than for triangular liners, as found by Gomez (2010). van der Tol et al. (2010) reported that a triangle liner distributed pressures more evenly over the teat surface, with lower maximum pressure on the teat end, than did a round liner. The reported concentration of pressure at the teat end by van der Tol et al. (2010) could be a possible explanation for the greater OP exhibited by round liners compared with triangular ones. The very low OP values for liner $\mathrm{F}(0 \mathrm{kPa})$ were due to the unique design

Table 3. Overpressure values by test order

\begin{tabular}{ll}
\hline Test order & LSM \pm SEM \\
\hline 1 & $14.99 \pm 1.46^{\mathrm{a}}$ \\
2 & $14.21 \pm 1.46^{\mathrm{b}}$ \\
3 & $13.09 \pm 1.46^{\mathrm{c}}$ \\
4 & $12.37 \pm 1.46^{\mathrm{d}}$ \\
\hline
\end{tabular}

${ }^{\mathrm{a}-\mathrm{d}}$ Different letters within a column denote significant difference $(P<$ $0.05)$. 
Table 4. Overpressure (OP) among 6 liners $(\mathrm{LSM} \pm \mathrm{SEM})$

\begin{tabular}{llc}
\hline Liner & Shape & OP \\
\hline Liner A & Round & $18.2 \pm 1.46^{\mathrm{a}}$ \\
Liner B & Round & $15.6 \pm 1.46^{\mathrm{b}}$ \\
Liner C & Round & $14.2 \pm 1.46^{\mathrm{c}}$ \\
Liner D & Triangular & $10.5 \pm 1.46^{\mathrm{d}}$ \\
Liner E & Triangular & $9.8 \pm 1.46^{\mathrm{d}}$ \\
Liner F & Triangular & $0.00^{1}$
\end{tabular}

${ }^{\mathrm{a}-\mathrm{d}}$ Different letters within a column denote significant difference $(P<$ 0.001).

${ }^{1}$ All values recorded as 0.0 ; SEM not calculable.

of this triangular liner. Zero OP values for this liner emphasize that OP is not a direct measure of LC and may have some limitations for liners that produce very low LC. The wide range of OP found across the different liner tested represents a useful addition to more complete liner characterization.

\section{ATS}

Liner compression measurements for 3 round liners, with ATS insertion depth of $60 \mathrm{~mm}$ and across the range of PD tested, are shown in Figure 3. The LC increased with increasing PD across the liner for all liners with the $\mathrm{LC}$ for the highest-compression liner (A) affected more by PD than liners B and C. Liner compression measurements were considerably higher when the ATS sensing surface was facing the flat side of the triangular liners than when the sensing surface was facing the corner of the triangular liners (Figure 4). This was likely because the flat plate in the center of the ATS interfered with the collapse of the triangular liners. The ATS was therefore not considered reliable for measuring LC for triangular liners.

The estimated LC in round liners $(\mathrm{A}, \mathrm{B}$, and $\mathrm{C}$ ) was positively correlated $\left(\mathrm{R}^{2}\right.$ for a linear fit ranging from 0.97 to 0.91 ) with the pressure difference across the liner wall from 30 to $50 \mathrm{kPa}$. Similar results were found by Davis et al. (2001) and Reinemann et al. (1994) when applying air pressure to the pulsation chamber. Although the results of the ATS for triangular liners is not entirely reliable, it does appear as if triangular liners showed less change in LC with pressure difference than did round liners. This could be related to differences in the collapse pattern between triangular and round liners observed by van der Tol et al. (2010). Physical inspection as well as measurements taken with the ATS indicate that some compression is applied by liner $\mathrm{F}$ when fully closed. Recall that this liner registered $0 \mathrm{kPa}$ on all OP measurements taken with the OPB.

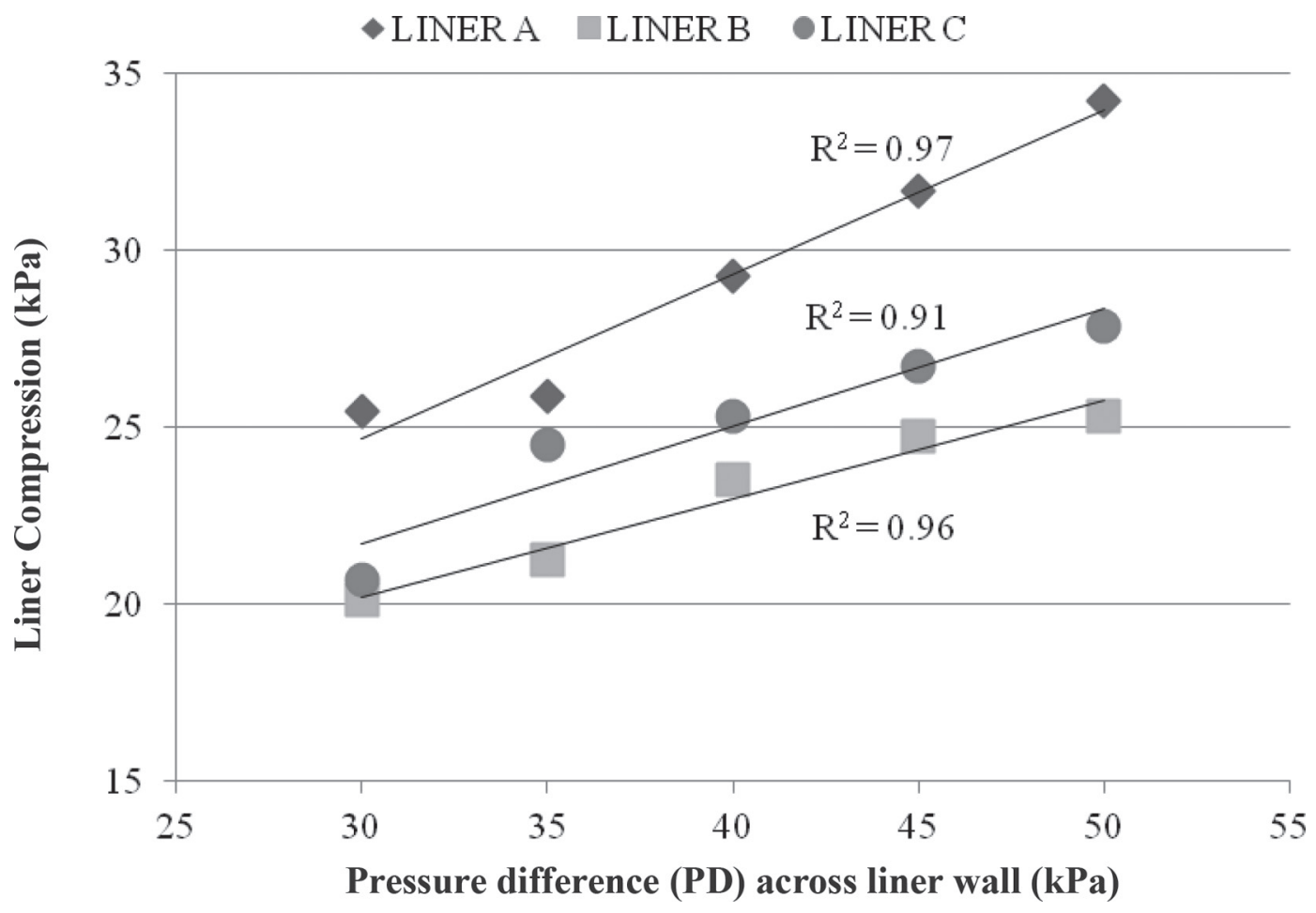

Figure 3. Liner compression (LC) applied to the artificial teat sensor (insertion depth of $60 \mathrm{~mm}$ ) for round liners tested applying vacuum of 30 to $50 \mathrm{kPa}$ to the short milk tube. 


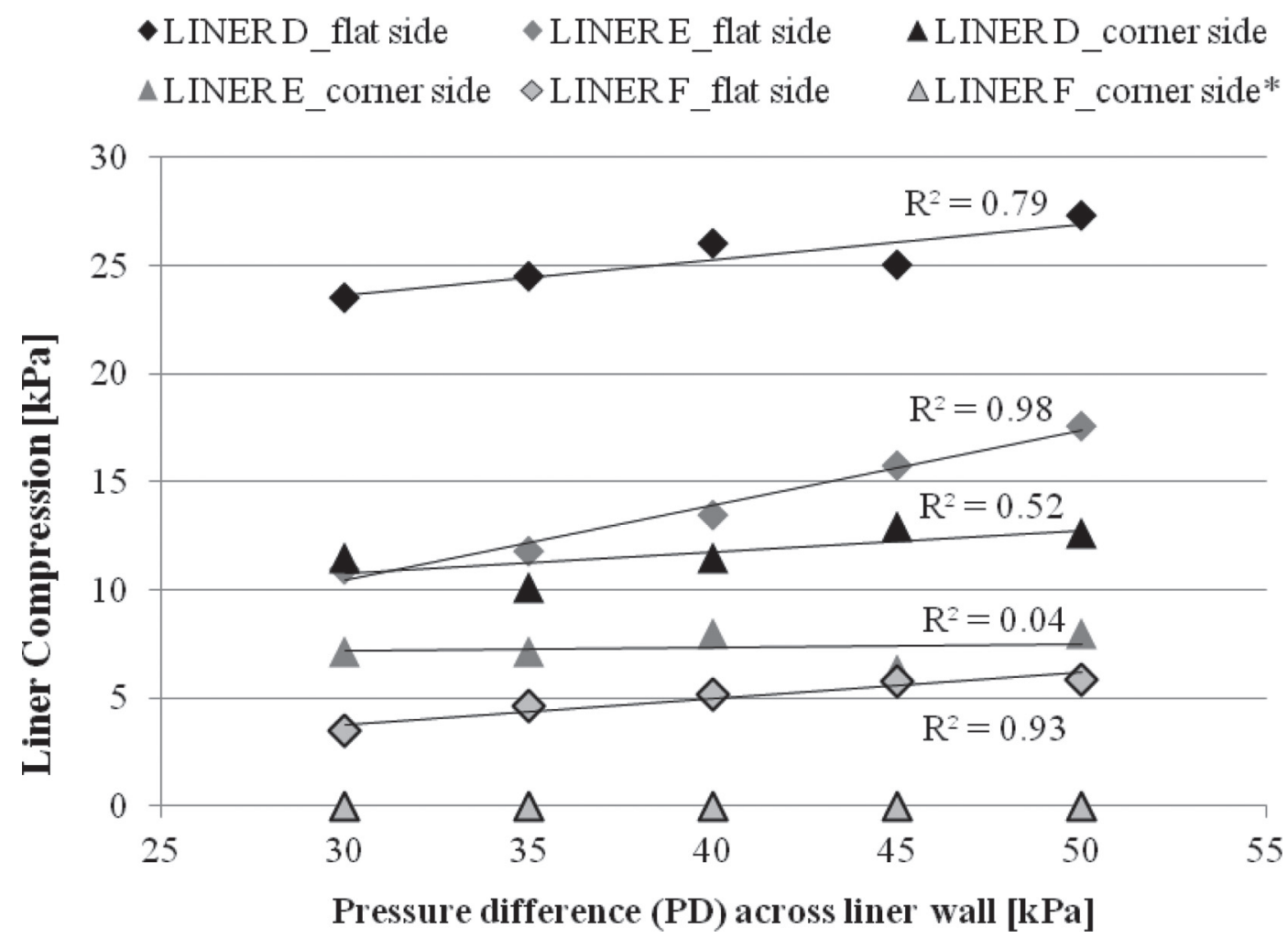

Figure 4. Liner compression (LC) applied to the artificial teat sensor (insertion depth of $60 \mathrm{~mm}$ ) by the triangular liners tested applying vacuum of 30 to $50 \mathrm{kPa}$ in the short milk tube and with the artificial teat sensor placed with the load cell facing the flat side and the corner side of the liner. For liner $\mathrm{F}, \mathrm{R}^{2}$ was not calculable.

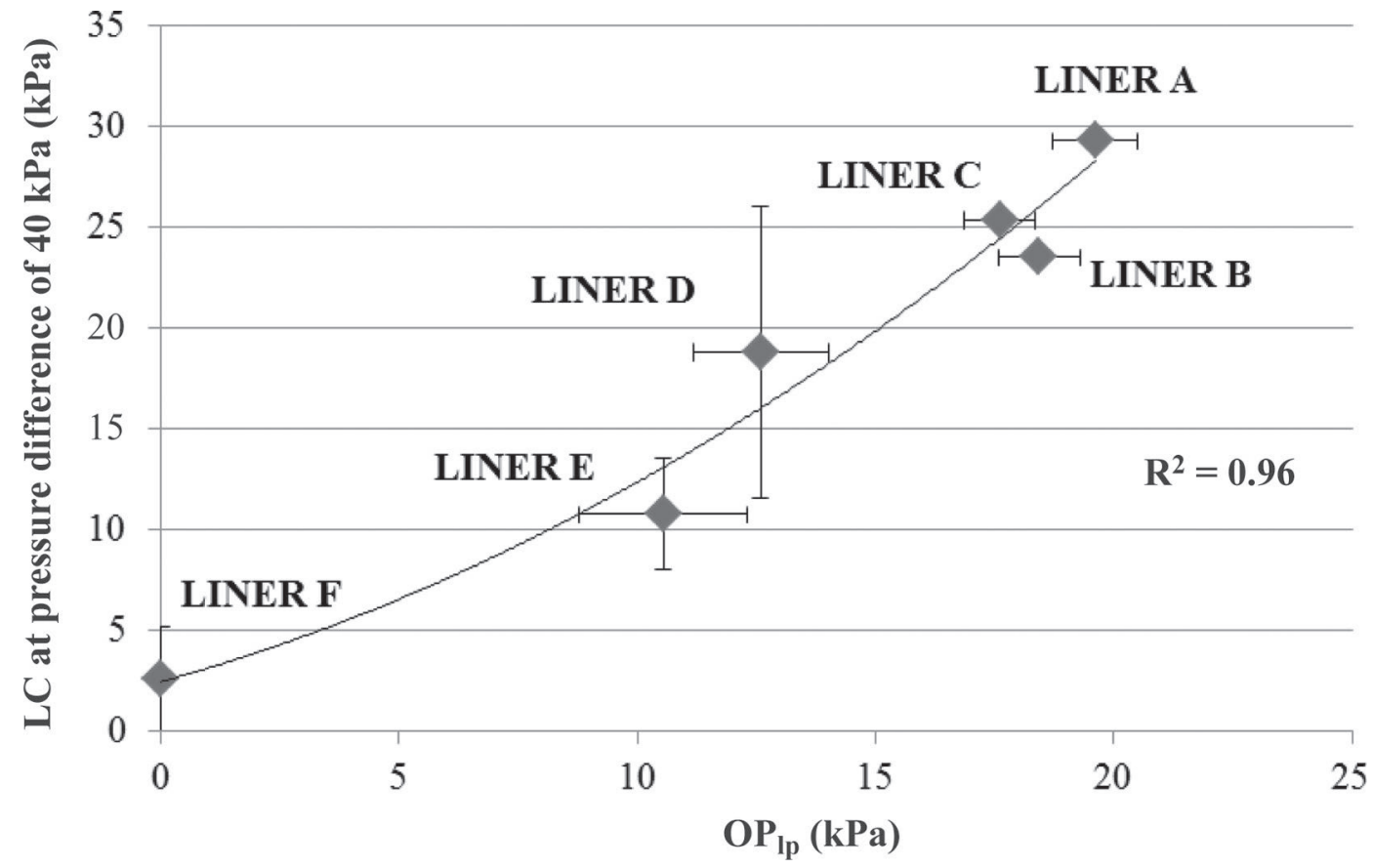

Figure 5. Relationship between overpressure measured with limited pulsation $\left(\mathrm{OP}_{\mathrm{lp}}\right) 1 \mathrm{~min}$ after unit attachment and liner compression (LC) measured with the artificial teat sensor (applying $40 \mathrm{kPa}$ of vacuum to the short milk tube, and insertion depth of $60 \mathrm{~mm}$ ) for the 6 liners tested. Values reported for the triangular liners (D, E, and F) are for the sensor facing the flat side and corner of the liner (maximum and minimum values; vertical bars) and the average of these 2 measurements (diamond); LSM and SEM (horizontal bars) reported in figure. 


\section{OP Versus LC Measurements}

The relationship between $\mathrm{OP}_{l p}$, using data from the test performed $1 \mathrm{~min}$ after unit attachment, and LC, for a vacuum level of $40 \mathrm{kPa}$ and insertion depth of 60 $\mathrm{mm}$, is shown in Figure 5. For the triangular liners, LC data are presented for both orientations of the sensor as well as the average value. The correlation between $\mathrm{OP}$ measurements and estimated $\mathrm{LC}$ values was very high, with a coefficient of determination of 0.96 for a quadratic model fit.

\section{CONCLUSIONS}

The $\mathrm{OP}_{l p}$ method showed significantly higher liner $\mathrm{OP}$ values than the $\mathrm{OP}_{\mathrm{np}}$ method $(0.5 \mathrm{kPa})$ and decreased over time. This difference was less than that previously reported in the literature. We recommend using the $\mathrm{OP}_{\mathrm{lp}}$ method with values recorded 1 min after the milking unit is attached to a well-stimulated udder to reduce the variability of the test and approximate normal milking conditions. The use of the ATS to estimate LC in triangular liners needs further investigation due to the particular collapsing characteristics of these liners and the resulting effect on sensor response.

\section{ACKNOWLEDGMENTS}

The authors thank Milkline S.r.l. (Podenzano, Italy) for building and providing the OP Bucket and for their support.

\section{REFERENCES}

Bade, R. D., D. J. Reinemann, M. Zucali, P. L. Ruegg, and P. D. Thompson. 2009. Interactions of vacuum, b-phase duration, and liner compression on milk flow rates in dairy cows. J. Dairy Sci. 92:913-921.

Butler, M. C. 1993. A mathematical model of the force exerted by the teatcup liner on the dairy cow's teat. J. Agric. Eng. Res. 54:211-217.

Caruolo, E. V. 1983. Measuring force of massage produced by the teatcup liner. J. Dairy Sci. 66:2441-2445.

Davis, M. A., D. J. Reinemann, and G. A. Mein. 2001. Development and testing of a device to measure compressive teat load applied to a bovine teat by the closed teatcup liner. Pages 1-13 in ASABE Ann. Intl. Mtg. Proc., Sacramento, CA. ASABE, St. Joseph, MI.

Gates, R. S., and N. R. Scott. 1986. Measurements of effective teat load during machine milking. Trans. ASAE 29:1124-1130.

Gomez, S. A. 2010. The interactive effect of linear characteristics, milking vacuum and pulsation settings on milking performance. MS Dissertation, University of Wisconsin, Madison.

Mein, G. A., and D. J. Reinemann. 2009. Biomechanics of milking: Teat-liner interactions. Paper Number: 09743 in ASABE Ann. Intl. Mtg. Proc., Reno, NV. ASABE, St. Joseph, MI.

Mein, G. A., D. J. Reinemann, and P. D. Thompson. 2013. Understanding the contribution of cyclic liner compression to effective pulsation. Proceedings of the 2013 Annual Meeting of the National Mastitis Council. NMC, Verona, WI.

Mein, G. A., and D. M. Williams. 1984. Liner massage and teat condition. Pages 4-18 in 23th Natl. Mastitis Counc. Ann. Mtg. Proc., Kansas City, MO. Natl. Mastitis Counc. Inc., Madison, WI.

Mein, G. A., D. M. Williams, and C. C. Thiel. 1987. Compressive load applied by the teatcup liner to the bovine teat. J. Dairy Res. 54:327-337.

Mein, G. A., M. D. Williams, and D. J. Reinemann. 2003. Effects of milking on teat-end hyperkeratosis: 1 . Mechanical forces applied by the teatcup liner and responses of the teat. Pages 114-123 in 42th Natl. Mastitis Counc. Ann. Mtg. Proc., Fort Worth, TX. Natl. Mastitis Counc. Inc., Madison, WI.

Neijenhuis, F., H. Barkema, H. Hogeveen, and J. Noordhuizen. 2001. Relationship between teat-end callosity and occurrence of clinical mastitis. J. Dairy Sci. 84:2664-2672.

Reinemann, D. J. 2012. The smart position on teat condition. Pages 124-131 in New Zealand Milk Quality Conference Proc., Hamilton, NZ. Dairy NZ, Hamilton, New Zealand.

Reinemann, D. J., and G. A. Mein. 2011. Unraveling the Mysteries of Liner Compression. Proc. of the 2011 Countdown Meeting, Melbourne Australia. Dairy Australia, Melbourne, Australia.

Reinemann, D. J., G. A. Mein, and K. Muthukumarappan. 1994. Forces applied to the bovine teat by the teatcup liner during machine milking. Report n. 94-D-052. XII CIGR World Congress. Milan, Italy. CIGR International Commission of Agricultural and Biosystems Engineering, Kyoto, Japan.

Thompson, P. D. 1978. Measurements for studying machine milking. Pages 176-185 in 17th Natl. Mastitis Counc. Ann. Mtg. Proc., Louisville, KY. Natl. Mastitis Counc. Inc., Madison, WI.

van der Tol, P. P. J., W. Schrader, and B. Aernouts. 2010. Pressure distribution at the teat-liner and teat-calf interfaces. J. Dairy Sci. 93:45-52.

Williams, D. M., G. A. Mein, and M. R. Brown. 1981. Biological responses of the bovine teat to milking: information from measurements of milk flow-rate within single pulsation cycles. J. Dairy Res. 48:7-21.

Zucali, M. R. D., D. J. Reinemann, A. Tamburini, and R. Bade. 2008. Effects of liner compression on teat end hyperkeratosis. Paper number: 083798 in ASABE Ann. Intl. Mtg. Proc., Providence, RI. ASABE, St, Joseph, MI. 